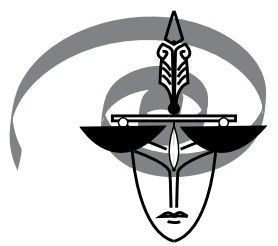

EUROPEAN

Volume $10 \cdot 2016 \cdot$ Number 3 (37)

DOI: 10.1515/ep-2016-0014

\author{
Jan Widacki” \\ Andrzej Frycz Modrzewski Kraków University, \\ Kraków, Poland
}

\title{
The First Polygraph?**
}

\section{Первый полиграф?}

Key words: Polygraph, Inc-Polygraph, History of Lie-Detection

In 1953, The Journal of Criminal Law, Criminology and Police Science (No. 5,pp. 679-681) published by the Northwestern University in Chicago reprinted an article by James Mackenzie on "The Ink Polygraph", originally published by the British Medical Journal in 1908 (Vol. 1, p. 1411).

Mackenzie's article was preceded by an introduction by Professor Fred E. Inbau (1909-98), an unquestioned authority not only on polygraph testing and interrogation techniques, but also on criminal trials and forensic studies (he was among others, a long-term director of the Crime Detection Laboratory). The material as a whole, i.e. Mackenzie's article together with Inbau's introduction is entitled "The First Polygraph".

\footnotetext{
* jan.widacki@gmail.com

** Project DEC-2013/11/B/HS5/03856 funded by National Science Centre.
} 
In his introduction to Mackenzie's article, Inbau remarked that when the history of lie detection techniques is discussed, hardly anyone notices that the name "polygraph" existed at least as early as 1906 (Inbau 1953, 678). He goes on to comment that the device in question, albeit constructed not for lie detection but for medical examinations, was nonetheless based on the same principles of construction as a lie detector. Following Fred Inbau, many authors repeated this information, as imprecise as it was untrue, suggesting that the device constructed by Mackenzie was the first one to be called "a polygraph" (Kniaziew, Warlamow 2012; Matte 1996).

In his article, Mackenzie wrote that at a meeting of the Medical Section of the British Medical Association in Toronto in 1906, he demonstrated a method of recording the movements of circulation by means of an ink polygraph. The polygraph recorded the circulation, registering pulse frequency and respiratory functions. This was nothing new, however. Since the end of the 19th century, respiration had been analysed with a pneumograph: a device that recorded the movements of the chest or diaphragm. The most popular construction was Marey's pneumograph, developed by a French scientist and inventor, Étienne-Jules Marey (1830-1904).

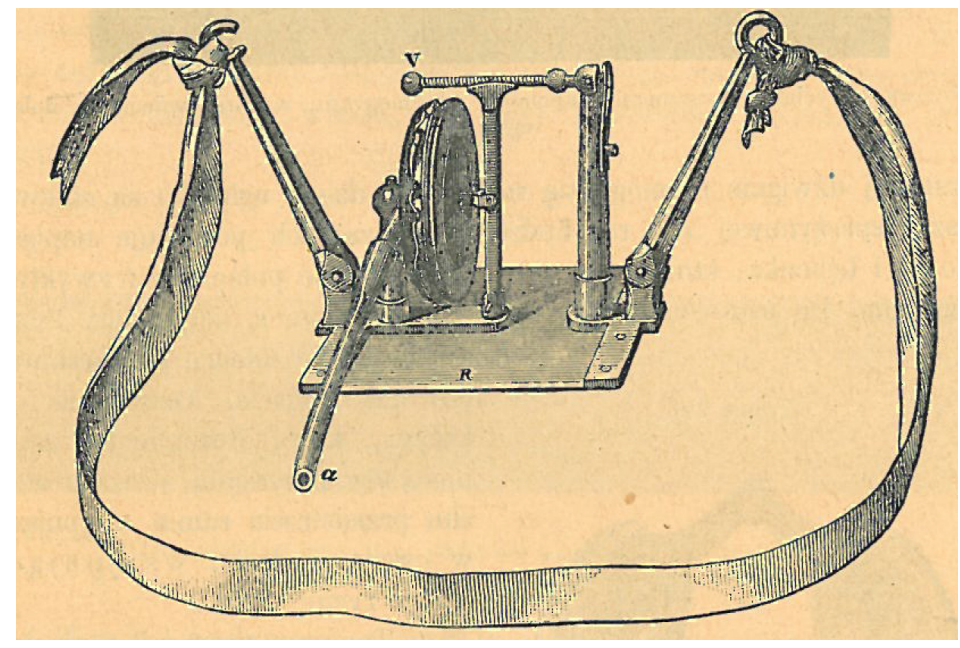

Fig. 1. Marey's pneumograph (N. Cybulski 1895).

Heart activity and blood circulation were observed with a sphygmograph, which made it possible to observe the pulse. The first sphygmograph was constructed in 1854 by a German physiologist, Karl von Vierordt (1818-84). It consisted of a bar placed on an artery that was fastened to the forearm with a strap. The movement of the bar was a function of pulsing of the artery. 


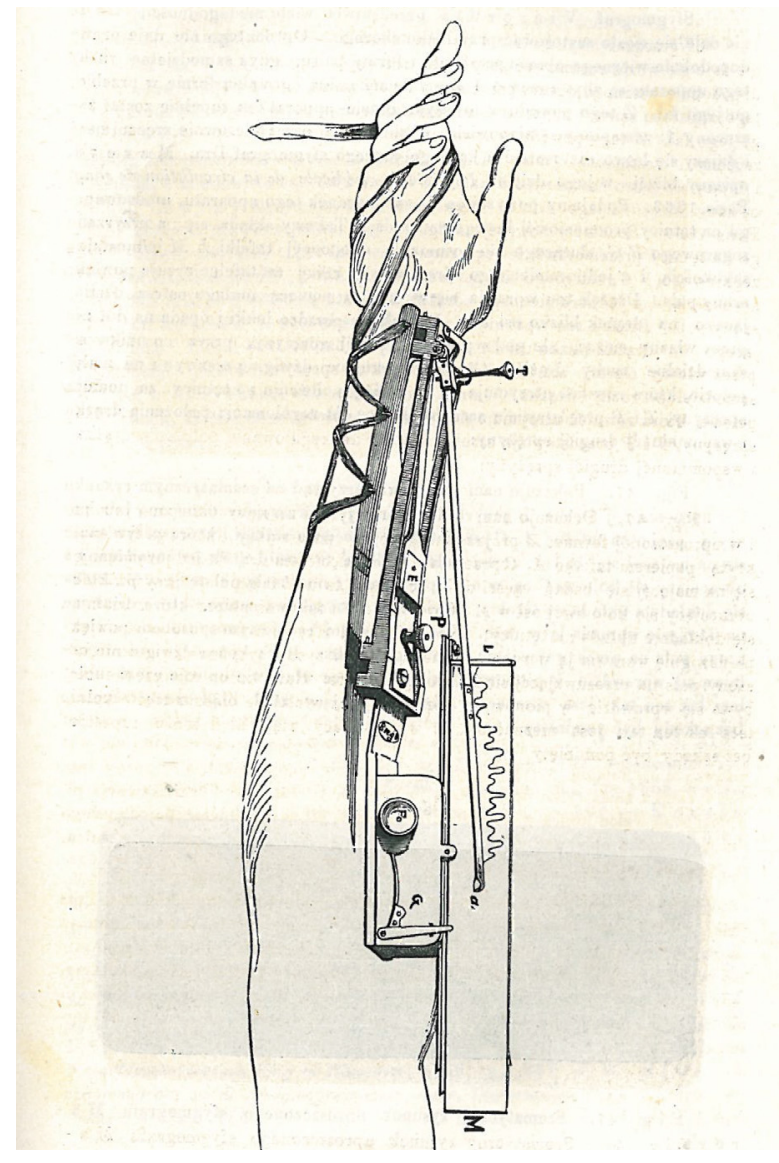

Fig. 2. Von Vierort's sphygmograph (H. Hoyer: Fizyologia, Warszawa 1872).

A design that could be connected to the pneumograph to produce the respiration curve, or with a sphygmograph to plot a curve recording the action of the heart (pulse beats), known as the kymograph, was constructed by a German physiologist, Karl Ludwig (1816-95). Some authors believe that the kymograph was constructed independent of Ludwig and even earlier, namely in 1846, by an Italian, Carlo Matteucci (Emeryk-Szajewska 2008). Its construction was relatively simple: a clockwork was attached to a drum and it was wrapped in a sheet of blackened paper revolving at a constant speed. The device, whether a sphygmograph or a pletysmograph, transmitted mechanical impulses collected by the original device to the stylus of the kymograph, which drew (or more precisely: erased), a white curve on the blackened sheet. 
The sphygmograph, sometimes also known as a cardiograph and combined with a kymograph, was used late in the 19th century in experiments conducted by Angelo Mosso (Mosso 1891) Cesare Lombroso (Lombroso 1891) and others. A pneumograph connected to a kymograph was used in the experiments of both Benussi (benussi 1914) and Abramowski (Abramowski 1913)
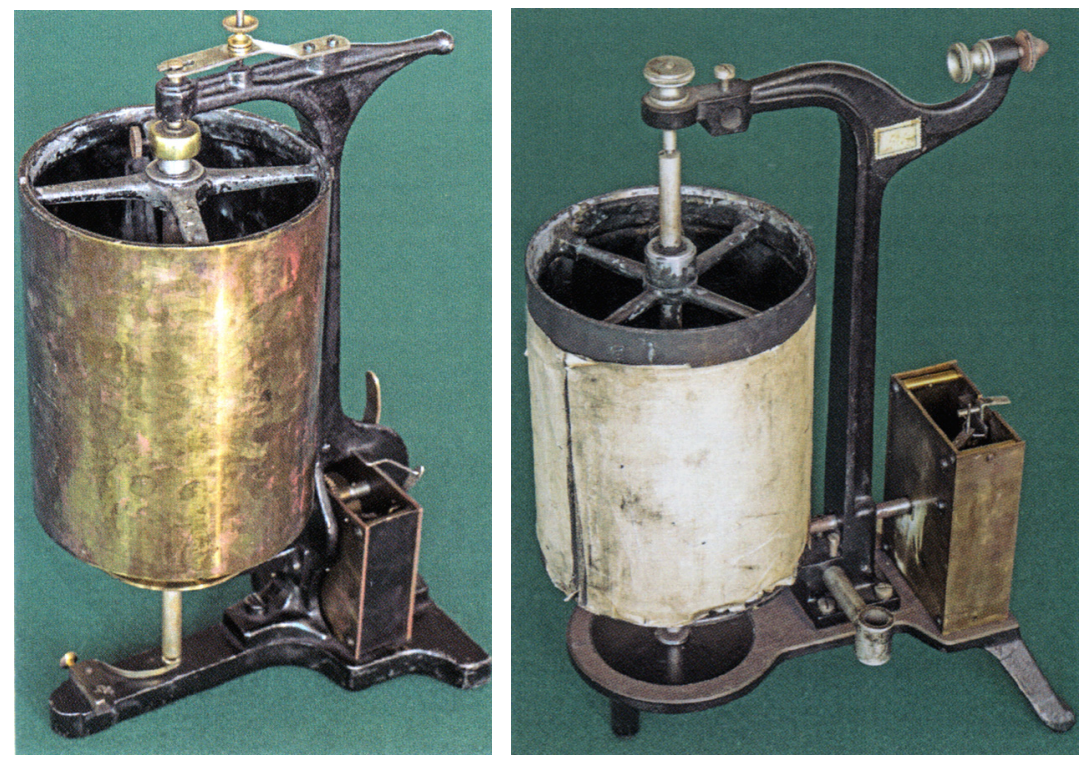

Fig. 3. Kymographs (Museum of the Jagiellonian University).

The kymograph was used as early as the 19th century for the simultaneous recording of data coming from the pneumograph and sphygmograph. The device thus constructed was known as a "polygraph", i.e. a device for recording more than one function (Greek: poloi - multiple, graphos - to write). Such a name was used to denote the combination of a kymograph with a sphygmograph or pneumograph in the 19th century by Napoleon Cybulski (Cybulski 1895) and somewhat later by Leon Zbyszewski (Zbyszewski 1914). Thus European continental literature had applied the name "polygraph" for at least over a decade before Mackenzie used it. This demonstrates that rather than inventing the name, Mackenzie just mentioned it. The range of devices he mentioned included "sphygmograph", "the polygraph", "the clinical polygraph", and "the ink polygraph".

According to Mackenzie, the clinical polygraph "can be used for taking, at the same time and on the same recording surface, tracings of the radial pulse, with tracings of 
the apex beat, carotid, venous, or liver pulse, or respiratory movements, and its size permits it being carried out with the greatest facility, and readily employed in general practice" (Mackenzie 1910, 68). He explains further that "the essential part of the instrument [clinical polygraph] is a small cup for receiving the impressions of the pulsations, a tube for transmitting the impressions to a tambour and the lever the tambour is attached to (...) sphygmograph" (Mackenzie 1910, 69).

The "ink polygraph" was an enhancement of the "clinical polygraph". Mackenzie arrived at the conclusion that "it was not convenient when the movements had to be recorded over a long period, as where the irregularities were infrequent, or where they varied, or where respiratory curves were required. [He] therefore conceived the idea of constructing an instrument that would take tracings of an indefinite length, where the employment of ink would enable a roll of paper to be unwound, and save as well the inconvenience of blackening and varnishing" (Mackenzie 1910, 72).

Subsequently, with his assistant S. Shaw, Mackenzie constructed a device called the "ink polygraph". The novelty was that rather than turning a drum wrapped in a sheet of paper, as in kymographs, the clockwork (A) set in motion a roll of paper (D). Another clockwork moved the time-marking pen (F), two tambours (BB) and their levers $(\mathrm{FF})$. The levers were connected to pens, and ink was poured into a small container and it reached the pens through capillaries.

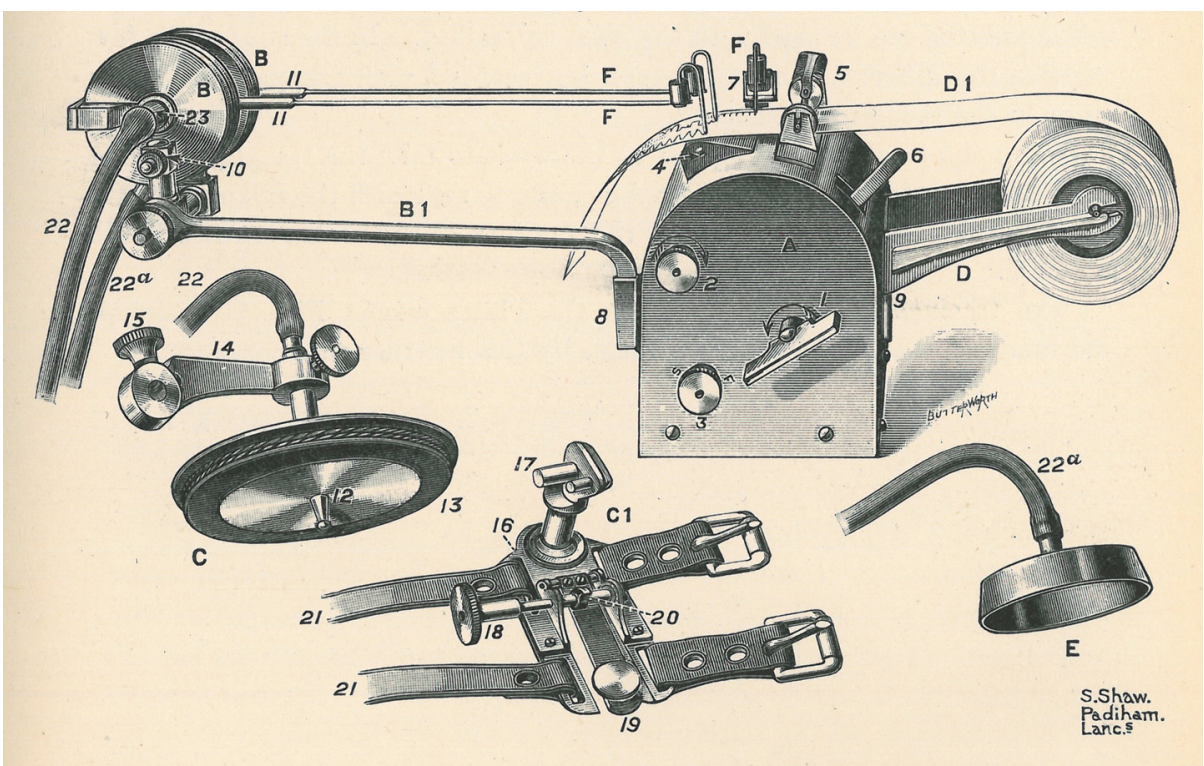

Fig. 4. The ink polygraph (J. Mackenzie 1910). 
There were two fundamental changes in the improvement introduced by Mackenzie. First, he replaced the tambour wrapped in blackened paper used in kymographs with a roll of paper. The stylus or slate pencil erasing a white curve on the blackened paper was replaced by an ink pen that drew a curve on the white roll. This was certainly a major development, and the upgraded system of recording was later used in analog polygraphs.

Thus, James Mackenzie certainly modernised the manner of recording physiological functions of the human organism that had been observed and recorded many years before him. It should likewise be recognised that he was not the first to use the name "polygraph" to denote a device that simultaneously records more than one single physiological function of the human organism as the name had been used over a decade before him for the combination of a sphygmograph and pneumograph with a kymograph.

\section{References}

Abramowski E. (1913): Oddech jako czynnik życia duchowego. Wzruszenie i wola., Prace z Psychologii Doświadczalnej, 1913, I, pp. 77-162 [in Polish].

Benussi V. (1914): Die Antmungssymptome der Lüge, Archiv ges. Psychol., 1914, 31, pp. 244-273.

Cybulski N. (1895): Fizyologia człowieka, 2nd ed. Vol. I, parts I and II, Kraków 1895, pp. 430-431 [in Polish].

Emeryk-Szajewska B. (2008): Krótka historia powstania i rozwoju elektromiografii i elektroneurologii [in:] Neurologia kliniczna, Vol. I, B. Emeryk-Szajewska, M. Niewiadomska-Wolska (eds.), Medycyna Praktyczna, Kraków 2008, pp. 47-54.

Kniaziev V., Varlamov G. (2012): Poligraf i ego prakticzeskoje nprimienienie, Moskwa 2012, p. 55.

Lombroso C. (1891): Człowiek zbrodniarz [Polish translation], Warszawa 1891-92.

Mosso A. (1891): Strach. Studium popularnonaukowe [Polish translation], Warszawa 1891, pp. 95 and ff.

Mackenzie J. (1908): The ink polygraph, British Medical Journal 1908, 1, 1411.

Mackenzie J. (1910): Diseases of the heart, 2an ed. Oxford University Press, London 1910.

Matte J. (1996): Forensic psychophysiology. Using the polygraph. Scientific truth verification-lie detection, J.A. M. Publications, Williamsville (N.Y.) 1996, p. 19.

Zbyszewski L. (1914): Fizyologia oddychania. Mechanizm i unerwienie, Drukarnia Uniwersytetu Jagiellońskiego, Kraków 1914, s. 22. 